\title{
Assessment of Physico-Chemical Properties of Tannery Waste Water and Its Impact on Fresh Water Quality
}

\author{
Shahida Parveen ${ }^{1}$, Ram Bharose ${ }^{1}$ and Dharam Singh ${ }^{2}$ \\ ${ }^{1}$ Department of Environmental Science, College of Forestry, Sam Higginbottom University of \\ Agriculture, Technology and Sciences, Allahabad, Uttar Pradesh- 211007, India \\ ${ }^{2}$ Department of Environmental Science, Chhatrapati Shahu Ji Maharaj University, Kanpur, \\ Uttar Pradesh-208024, India \\ *Corresponding author
}

\section{A B S T R A C T}

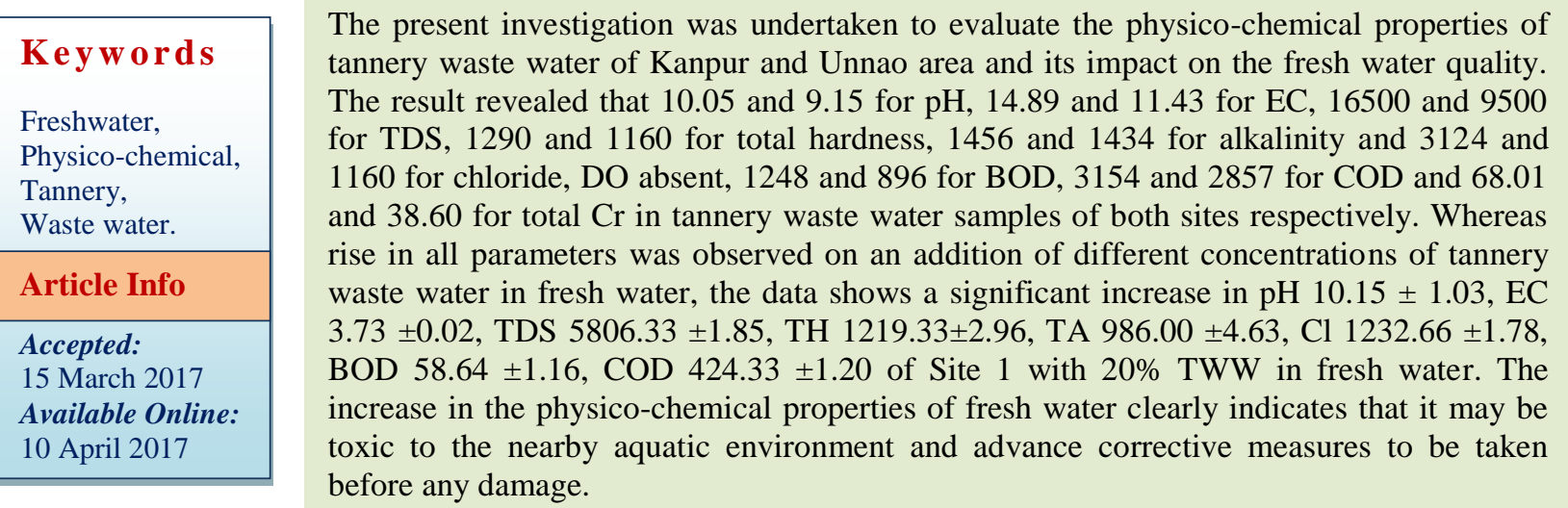

\section{Introduction}

Industrial and urban development has become an important factor for the development of a country's economy. The tannery industry is one of the oldest industries, which is unevenly scattered and more than 2,500 tanneries are located in different urban centers of India processing about 500,000 tonnes of hides and $314 \mathrm{~kg}$ skins per annum which generate about $100,000 \mathrm{~m}^{3}$ of wastewater per day (Mohan et $a l ., 2006)$ which alters the physical, chemical and biological properties of the aquatic environment. Tanning and finishing industry in India is concentrated in Madras, Ranipet, Amber Vaniyambadi, Erode, Dindigul,
Permabut, Agra, Calcutta, Maharashtra, West Bengal, Rajasthan, Punjab, Kanpur (Jajmau) and Unnao area of Uttar Pradesh (Vijayan and and Hempriya, 2014).

Tannery industries consume a considerable amount of water in their manufacturing processes and serve as a major source of tanned and untanned solid waste and liquid effluents which contain high organic load, salts and chromium, releasing about 40 $25,000 \mathrm{mg} / \mathrm{L}$ of chromium in their effluent (Obgonna et al., 2008). Most developing countries without any treatment directly 
discharge tannery effluent into aqueous system (Farenzena et al., 2005) which is highly polluted in terms of biological oxygen demand (BOD), chemical oxygen demand (COD), suspended solids (SS), nitrogen, conductivity, sulphate, sulphide and chromium (Wosnie and Wondie, 2014).

Dissolved organic contents consume a large amount of oxygen and increase BOD level which leads to anaerobic fermentation and produces organic acids and hydrolysis of these organic acids causes the decrease in $\mathrm{pH}$ values (Ahmed et al., 2011). High TDS, BOD and COD content cause decrease in DO of the water system creating stress condition to the aquatic living organisms (Kambole, 2003). Degradation of dissolved organic contents generates cations and anions and changes in the ionic composition of water which can also exclude some species while promoting population growth of others (Scannell and Duffy, 2007). Das et al., (2010) have also reported a higher amount of TDS, BOD, COD, EC, salinity, alkalinity, hardness and lower amount of DO in tannery effluent.

$\mathrm{Cr}$ is one of the most important pollutants released from the tanning industries and the biggest problem is its disposal and recovery. Compared to the recommended permissible limit of $2 \mathrm{mg} / \mathrm{L}$ prescribed by BIS, India alone released about 2000-3000 tons of chromium into the environment annually from tanneries with chromium concentrations ranging between $40-5000 \mathrm{mg} / \mathrm{L}$. Chromium is a potential pollutant and well known for its mutagenicity (Cheng and Dixon, 1998) and carcinogenicity (Wang et al., 1999) effects in humans, animals and plants. Soil profile, surface water bodies (ponds and rivers), human health, fishes and other aquatic biodiversities are at risk of serious threat due to the extensive use of chromium in tanning industries and discharge of wastewater (Mohanta et al., 2010). In a study conducted by Blacksmith Institute about $75 \%$ of chromium sites located in South Asia out of them, a third are associated with tannery operations, with mining and metallurgy sites. Due to the abundance of tanneries, South Asia has highly concentrated chromium sites. Many of these tanneries have poor environmental controls and are regarded as a threat to the environment (Azom et al., 2012).

The aim of the present study is to evaluate the dilution effect of tannery waste water on fresh water quality. The Indian industries function under the strict guidelines of the Central Pollution Control Board (CPCB) but the situation of environmental pollution is still far from satisfactory results (Lokhande et al., 2011) industries in India despite working under strict guidelines of central pollution control board are still in continuous criticism. Over all tanneries waste water play a significant role in deteriorating the quality freshwater system. Keeping in view the importance of the study the present investigation was conducted to evaluate the physico-chemical properties of the tannery waste water of Kanpur and Unnao area of Uttar Pradesh and its impact on the fresh water quality

\section{Materials and Methods}

The present study was conducted collaboratively in laboratory Department of Environmental Science, College of Forestry, SHUATS and laboratory of Environmental science, I.B.S.B.T., C.S.J.M. University Kanpur.

\section{Study area}

Effluent samples for the study work were taken from one of the tannery industry from Jajmau area of Kanpur district and second sample from Banthar, Unnao District of Uttar Pradesh, India. The study area of Kanpur 
District (Kanpur Nagar District) is one of the famous districts Uttar Pradesh, India. Currently Kanpur, is very famous for Leather Industry in the world. The district lies between $25^{\circ} 25^{\prime}$ and $25^{\circ} 54^{\prime}$ latitudes and $79^{\circ}$ $34^{\prime}$ and $80^{\circ} 34^{\prime}$ longitudes. Kanpur is bounded by Kannauj and Hardoi in north, Unnao in east, Fatehpur and Hamirpur in south and Kanpur Dehat in west. The Holy Ganga River separates it from district Unnao in east and forms the natural boundary. River Pandu separates it from district Kanpur Dehat and Fatehpur in west and south respectively. The total geographical area of district Kanpur Nagar is 3155 sq. Kms as per record. The major cluster of tanneries at Kanpur is located in Jajmau area. Jajmau is located on the right bank of river Ganga on the north eastern border of Kanpur city and there are 400 tanneries in the cluster. The Jajmau area of Kanpur has 04 major drains. The drains mainly carry storm water as well as industrial effluent and join the river, Ganga.

On the other hand the Unnao is another township across the Ganga about $20 \mathrm{~km}$ from Jajmau situated between rivers Ganga and Sai, The District lies in between Latitude $26^{\circ} 8^{\prime} \mathrm{N}$ and $27^{\circ} 2^{\prime} \mathrm{N}$ and Longitude $80^{\circ} 3^{\prime} \mathrm{E} \&$ $81^{\circ} 3^{\prime} \mathrm{E}$. It is bounded by Hardoi on the North, Lucknow on the East, Rae Bareli on the South and Ganga on the West which separates it from Kanpur \& Fatehpur. Its Geographical area is 4589 sq. $\mathrm{km}$. The main rivers of the district are Ganga which form the western and southern boundary and the Sai which forms the northern and eastern boundary. Adjoining to Kanpur the town of Unnao also has some tanneries and about 20 are situated in this area. Leather Technology Park in Banthar, Unnao is dedicated to Leather Industry Development and environment protection of Unnao. The treated effluents are discharged (through the UPSIDC drainage) finally into the City Jail drain which ultimately meets the river Ganga (Fig. 1).

\section{Effluent sample collection}

The treated tannery effluent was collected in a plastic container (Tarson) from Jajmau, Kanpur nagar and Banthar, Unnao, Districts Uttar Pradesh, India.

\section{Physico-chemical analysis of effluent and water sample}

Water analysis was done following the standard methods of (APHA, 1998). The physico-chemical characteristics such as temperature, $\mathrm{pH}, \mathrm{EC}$, TDS (total dissolved solids), Total hardness, Total alkalinity, chloride, DO (dissolved oxygen), BOD (Biological Oxygen Demand), COD (Chemical Oxygen Demand). The $\mathrm{pH}$ and EC were measured by digital portable kit (model pp9040) portable battery operated with glass and calomel electrodes.

\section{Metal estimation}

Metal concentration was estimated by the method of Piper, (1942) for this purpose, $1000 \mathrm{ml}$ of effluent and different concentration of tannery wastewater samples were taken in the conical flask and evaporated till dried. The dried samples were digested in 10:1 $\mathrm{HNO}_{3}: \mathrm{HClO}_{4}(\mathrm{v} / \mathrm{v})$. The white crystals were found in digested samples and these crystals were dissolved in $10 \mathrm{ml}$ double distilled water. The supernatant was filtered through Whatman Number 1 filter paper and was read directly with Atomic Absorption Spectrophotometer (Thermo scientific iCE3300 FL AA System, designed in UK and made in China.) for estimation of total $\mathrm{Cr}$ content. The acetylene gas was used for the estimation of $\mathrm{Cr}$.

\section{Statistical analysis}

The data observed in the experiments were statistically analyzed for the calculation of 
standard error (S.E.) and one way ANOVA for testing the hypothesis with the help of computer software IBM SPSS Statistics $21.0 \times 86$ program. The data shown are the average of three replicates \pm S.E.

\section{Results and Discussion}

The physico-chemical characteristics of treated tannery wastewater of both sites are shown in table 1. All the parameters in tannery waste water like $\mathrm{pH}, \mathrm{EC}$, TDS, Total hardness, total alkalinity, Chloride, BOD, $\mathrm{COD}$ and $\mathrm{Cr}$ were found higher than prescribed limit of BIS.

From table 2 it's revealed that the physicochemical characteristics of the fresh water which is the addition of different concentration of tannery waste water to the fresh water. In experimental water the $\mathrm{pH}$, EC, total hardness (TH), total alkalinity (TA), chloride, BOD, COD and $\mathrm{Cr}$ of test medium increased on addition of each concentration of tannery wastewater $(5 \%, 10 \%, 15 \%$ and $20 \%$ Tannery wastewater) with fresh water respectively while the dissolved oxygen (DO) was observed decreased with increase in concentration of tannery waste water.

The results of the tannery waste water revealed that the color of the effluent was dark brown at both sites (site-1 and site-2) with the unpleasant foul smell. Similar results were reported by Smrithi and Usha, (2012) and Bhatnagar et al., (2013) that the color of the effluent may be due to the presence of biodegradable and non-biodegradable organic compounds and high amounts of inorganic chemicals like sodium and chromium used during processing and the odour may be due to the putrefaction of organic residues from the processed skins and hides (Table 1).

pH- One of the most important characteristic of the water is $\mathrm{pH}$ and any slight changes can affect the $\mathrm{pH}$ level of water making it unfit for drinking and other purposes. The higher value of $\mathrm{pH}$ shows that the $\mathrm{pH}$ of tannery waste water was alkaline in nature which is above the permissible limit of 5.0 to 9.0 given by BIS. Maximum $\mathrm{pH}$ was observed in $20 \%$ concentration of tannery wastewater 10.15 and 9.13 at both site- 1 and site -2 respectively. The alkaline nature of the tannery effluent is due to the presence of carbonates and bicarbonate. Similar results were reported by Navaraj and Yasmin, (2012).

EC-Conductivity is a measure of its ability to conduct electricity and also an indirect measurement of salt content present in water. The maximum EC was observed 3.73 and $3.14 \mathrm{dSm}^{-1}$ at both sites 1 and 2. Elevated level of conductivity is due to the presence of chloride ions and inorganic salt cations $\left(\mathrm{Na}^{+}\right.$, $\mathrm{K}^{+}, \mathrm{Ca}^{2+}$ and $\mathrm{Fe}^{3+}$ ) that creates more salinity in water. Murali et al., (2013) reported similar results of higher conductivity in untreated and treated tannery effluent indicating higher discharge of chemicals as cations and anions in waste water.

TDS- Total Dissolved Solids (TDS) is the measure of total inorganic salts and other dissolved substances in water. In the present experiment, the TDS was found much greater than the prescribed limit of BIS $\left(2100 \mathrm{mgL}^{-1}\right)$. The maximum TDS was observed 5806 and $1874 \mathrm{mgL}^{-1}$ in $20 \%$ TWW at sie- 1 and site- 2 respectively. Higher values of TDS are due to the presence of dissolved organic and inorganic impurities. Das et al., (2010) have also reported similar results of the increase in TDS.

\section{Hardness}

Hardness is a chemical parameter of water that represents the total concentration of calcium, magnesium, carbonates, bicar- 
bonates, sulphates, chlorides, nitrates, toxic metals and organic matter. The maximum hardness was observed 1219.33 and 876.66 $\mathrm{mgL}^{-1}$ in $20 \%$ TWW at both sites 1 and 2 . Sugasini and Rajgopal, (2015) have also reported the increase in hardness.

\section{Alkalinity}

Total alkalinity represents the quantity of base present in water. The presence of bicarbonates, carbonates, phosphates, hydroxides, etc causes an increase in alkalinity level.

In the present study, the maximum alkalinity was observed 986.00 and $686.00 \mathrm{mgL}^{-1}$ in $20 \%$ TWW at both sites-1 and 2. Noorjahan, (2014) have also reported similar findings of alkalinity.

\section{Chloride}

Chloride present in water is used as a disinfectant and according to BIS maximum permissible limit for chloride in discharged effluent is $1000 \mathrm{mgL}^{-1}$. The maximum $\mathrm{Cl}$ was observed 1232.66 and $943.66 \mathrm{mgL}^{-1}$ in $20 \%$ TWW at both site-1 and 2. Presence of chloride in tannery effluents is the result of addition of $\mathrm{NaCl}$ in the large quantity of common salts for the preservation and pickling processes of skins and hides. The presence of chloride ions increases the salinity of the receiving water body. The high value of chlorides in effluents pollutes the drinking water making it suitable for easy growth of microbes, leading to water borne diseases. Sugasini and Rajgopala (2015) have also reported similar findings.

Table.1 Physico- chemical characteristics of tannery waste water

\begin{tabular}{|c|c|c|c|c|}
\hline S.N. & Parameters & $\begin{array}{c}\text { Site }-1 \\
\text { (Kanpur) }\end{array}$ & $\begin{array}{c}\text { Site -2 } \\
\text { (Unnao) }\end{array}$ & $\begin{array}{c}\text { BIS Standard of } \\
\text { effluent discharged } \\
\text { (IS:2296-1982) }\end{array}$ \\
\hline 1. & Colour & Dark brown & $\begin{array}{c}\text { Dark } \\
\text { brown }\end{array}$ & - \\
\hline 2 & Odour & Foul smell & Foul smell & - \\
\hline 3 & $\mathrm{pH}$ & 10.05 & 9.15 & $5.5-9.0$ \\
\hline 4 & EC $\left.(\mathrm{dSm})^{-1}\right)$ & 14.89 & 11.43 & 8.50 \\
\hline 5 & TDS $\left(\mathrm{mgL}^{-1}\right)$ & 16500 & 9500 & 2100 \\
\hline 6 & T. Hardness $\left(\mathrm{mgL}^{-1}\right)$ & 1290 & 1160 & 600 \\
\hline 7 & T. Alkalinity $\left(\mathrm{mgL}^{-1}\right)$ & 1456 & 1434 & 1000 \\
\hline 8 & Chloride $\left(\mathrm{mgL}^{-1}\right)$ & 3124 & 1163 & Nil \\
\hline 9 & D.O. $\left(\mathrm{mgL}^{-1}\right)$ & Nil & Nil & 30 \\
\hline 10 & B.O.D. $\left(\mathrm{mgL}^{-1}\right)$ & 1248 & 896 & 250 \\
\hline 11 & C.O.D $\left(\mathrm{mgL}^{-1}\right)$ & 3154 & 2857 & 2 \\
\hline 12 & Chromium $\left(\mathrm{mgL}^{-1}\right)$ & 68.01 & 38.60 & \\
\hline
\end{tabular}


Table.2 Physico-chemical characteristic of experimental water

\begin{tabular}{|c|c|c|c|c|c|c|c|c|c|c|c|}
\hline \multirow{2}{*}{$\begin{array}{l}\text { Study } \\
\text { Area }\end{array}$} & \multirow[t]{2}{*}{ Treatments } & \multicolumn{10}{|c|}{ Parameters } \\
\hline & & pH & EC & TDS & TH & TA & $\mathbf{C l}$ & DO & BOD & COD & $\mathrm{Cr}$ \\
\hline $\mathrm{Si}$ & 101 & $\begin{array}{c}7.52 \\
\pm 0.02\end{array}$ & $\begin{array}{l}0.98 \\
\pm 0.00 \\
\end{array}$ & $\begin{array}{l}501.66 \\
\pm 4.40\end{array}$ & $\begin{array}{c}238.00 \\
\pm 1.15\end{array}$ & $\begin{array}{c}263.35 \\
\pm 0.88 \\
\end{array}$ & $\begin{array}{l}84.77 \\
\pm 0.61 \\
\end{array}$ & $\begin{array}{c}6.96 \\
\pm 0.04 \\
\end{array}$ & $\begin{array}{c}1.91 \\
\pm 0.03 \\
\end{array}$ & $\begin{array}{l}12.63 \\
\pm 0.16\end{array}$ & $\begin{array}{l}0.09 \\
\pm 0.00\end{array}$ \\
\hline $\mathrm{S}$ & or & $\begin{array}{c}7.46 \\
\pm 0.03\end{array}$ & $\begin{array}{l}0.98 \\
\pm 0.00\end{array}$ & $\begin{array}{c}501.66 \\
\pm 4.40\end{array}$ & $\begin{array}{c}238.00 \\
\pm 1.15\end{array}$ & $\begin{array}{l}259.66 \\
\pm 0.88\end{array}$ & $\begin{array}{l}87.00 \\
\pm 1.15\end{array}$ & $\begin{array}{l}6.96 \\
\pm 0.04\end{array}$ & $\begin{array}{c}1.91 \\
\pm 0.03\end{array}$ & $\begin{array}{l}12.33 \\
\pm 0.16\end{array}$ & $\begin{array}{c}0.09 \\
\pm 0.00\end{array}$ \\
\hline $\mathrm{Si}$ & $5 \%$ TWW & $\begin{array}{c}8.43 \\
\pm 0.07\end{array}$ & $\begin{array}{l}1.58 \\
\pm 0.02\end{array}$ & $\begin{array}{c}1309.00 \\
\pm 3.78\end{array}$ & $\begin{array}{l}662.66 \\
\pm 3.52\end{array}$ & & $\begin{array}{c}338.66 \\
\pm 1.20\end{array}$ & $\begin{array}{c}6.29 \\
\pm 0.28\end{array}$ & $\begin{array}{l}10.75 \\
\pm 0.05\end{array}$ & $\begin{array}{c}118.00 \\
\pm 3.05\end{array}$ & $\begin{array}{c}3.15 \\
\pm 0.00\end{array}$ \\
\hline Site 2 & $5 \%$ TWW & $\begin{array}{c}8.10 \\
\pm 0.02\end{array}$ & $\begin{array}{l}1.18 \\
\pm 0.01\end{array}$ & $\begin{array}{c}747.33 \\
\pm 2.40\end{array}$ & $\begin{array}{c}354.33 \\
\pm 2.60\end{array}$ & $\begin{array}{c}588.33 \\
\pm 1.20\end{array}$ & $\begin{array}{c}220.66 \\
\pm 3.17\end{array}$ & $\begin{array}{c}6.62 \\
\pm 0.29\end{array}$ & $\begin{array}{c}3.68 \\
\pm 0.01\end{array}$ & $\begin{array}{l}98.66 \\
\pm 5.20\end{array}$ & $\begin{array}{c}2.31 \\
\pm 0.00\end{array}$ \\
\hline S & $10 \%$ TWW & $\begin{array}{c}8.62 \\
\pm 0.07\end{array}$ & $\begin{array}{l}2.48 \\
\pm 0.00\end{array}$ & $\begin{array}{c}1857.33 \\
\pm 3.71\end{array}$ & $\begin{array}{c}863.33 \\
\pm 1.20\end{array}$ & $\begin{array}{c}896.66 \\
\pm 1.20\end{array}$ & $\begin{array}{c}833.66 \\
\pm 1.85\end{array}$ & $\begin{array}{c}5.57 \\
\pm 0.19\end{array}$ & \begin{tabular}{|l|}
31.81 \\
\pm 1.21 \\
\end{tabular} & $\begin{array}{c}123.27 \\
\pm 1.96\end{array}$ & $\begin{array}{c}4.92 \\
\pm 0.00\end{array}$ \\
\hline e 2 & $10 \% \mathrm{TWW}$ & $\begin{array}{c}8.52 \\
\pm 0.03\end{array}$ & $\begin{array}{l}2.42 \\
\pm 0.03\end{array}$ & $\begin{array}{c}987.33 \\
\pm 2.40\end{array}$ & $\begin{array}{c}556.00 \\
\pm 3.46\end{array}$ & $\begin{array}{c}616.00 \\
\pm 1.52\end{array}$ & $\begin{array}{c}657.66 \\
\pm 1.45\end{array}$ & $\begin{array}{c}6.07 \\
\pm 0.02\end{array}$ & $\begin{array}{c}5.86 \\
\pm 0.04\end{array}$ & $\begin{array}{c}175.33 \\
\pm 3.52\end{array}$ & $\begin{array}{c}3.12 \\
\pm 0.00\end{array}$ \\
\hline Site 1 & $15 \% \mathrm{~T}$ & $\begin{array}{c}9.53 \\
\pm 0.02\end{array}$ & $\begin{array}{l}3.65 \\
\pm 0.03\end{array}$ & $\begin{array}{c}3155.00 \\
\pm 2.88\end{array}$ & $\begin{array}{c}1083.33 \\
\pm 4.80\end{array}$ & $\begin{array}{c}962.33 \\
\pm 1.45\end{array}$ & $\begin{array}{c}1140.00 \\
\pm 3.78\end{array}$ & $\begin{array}{c}5.19 \\
\pm 0.04\end{array}$ & \begin{tabular}{|c|}
$45.37 \pm$ \\
2.33 \\
\end{tabular} & $\begin{array}{c}325.33 \\
\pm 2.90\end{array}$ & $\begin{array}{c}7.71 \\
\pm 0.00 \\
\end{array}$ \\
\hline Site 2 & $15 \%$ TWW & $\begin{array}{c}8.65 \\
\pm 0.01\end{array}$ & $\begin{array}{l}3.04 \\
\pm 0.04\end{array}$ & $\begin{array}{c}1322.00 \\
\pm 5.03\end{array}$ & $\begin{array}{c}683.33 \\
\pm 2.40\end{array}$ & $\begin{array}{c}649.00 \\
\pm 1.52\end{array}$ & $\begin{array}{c}754.00 \\
\pm 2.08\end{array}$ & $\begin{array}{c}5.83 \\
\pm 0.08\end{array}$ & $\begin{array}{l}10.56 \\
\pm 0.78\end{array}$ & $\begin{array}{c}289.33 \\
\pm 1.33\end{array}$ & $\begin{array}{c}5.48 \\
\pm 0.00\end{array}$ \\
\hline Site 1 & $20 \%$ TWW & $\begin{array}{r}10.15 \\
\pm 1.03\end{array}$ & $\begin{array}{l}3.73 \\
\pm 0.02\end{array}$ & $\begin{array}{c}5806.33 \\
\pm 1.85\end{array}$ & $\begin{array}{c}1219.33 \\
\pm 2.96\end{array}$ & $\begin{array}{c}986.00 \\
\pm 4.63\end{array}$ & $\begin{array}{c}1232.66 \\
\pm 1.78\end{array}$ & $\begin{array}{c}5.09 \\
\pm 0.01\end{array}$ & $\begin{array}{l}58.64 \\
\pm 1.16\end{array}$ & $\begin{array}{c}424.33 \\
\pm 1.20\end{array}$ & $\begin{array}{r}13.89 \\
\pm 0.03\end{array}$ \\
\hline Site 2 & $20 \%$ TWW & $\begin{array}{l}9.13 \\
\pm 0.06\end{array}$ & $\begin{array}{l}3.14 \\
\pm 0.03 \\
\end{array}$ & $\begin{array}{c}1874.00 \\
\pm 6.42 \\
\end{array}$ & $\begin{array}{c}876.66 \\
\pm 2.84\end{array}$ & $\begin{array}{c}686.00 \\
\pm 1.57\end{array}$ & $\begin{array}{c}943.66 \\
\pm 2.33\end{array}$ & $\begin{array}{c}5.76 \\
\pm 0.03 \\
\end{array}$ & $\begin{array}{r}11.75 \\
\pm 0.62 \\
\end{array}$ & $\begin{array}{c}335.66 \\
\pm 2.96\end{array}$ & $\begin{array}{c}8.82 \\
\pm 0.00 \\
\end{array}$ \\
\hline
\end{tabular}

Site 1= Kanpur, Site 2= Unnao, TWW= Tannery Waste Water, pH= potentio Hydrogeni, EC=Electrical conductivity $\left(\mathrm{dSm}^{-1}\right)$, TDS=Total Dissolved Solids $\left(\mathrm{mgL}^{-1}\right)$, $\mathbf{T H}=$ Total Hardness $\left(\mathrm{mgL}^{-1}\right), \mathbf{T A}=$ Total Alkalinity $\left(\mathrm{mgL}^{-1}\right), \mathbf{C l}=$ Chloride $\left(\mathrm{mgL}^{-1}\right), \mathbf{D O}=$ Dissolved Oxygen $\left(\mathrm{mgL}^{-1}\right)$, BOD=Biological Oxygen Demand $\left(\mathrm{mgL}^{-1}\right), \mathbf{C O D}=$ Chemical Oxygen Demand $\left(\mathrm{mgL}^{-1}\right), \mathbf{C r}=$ Chromium $\left(\mathrm{mgL}^{-1}\right)$ 
Fig.1 Map of study area

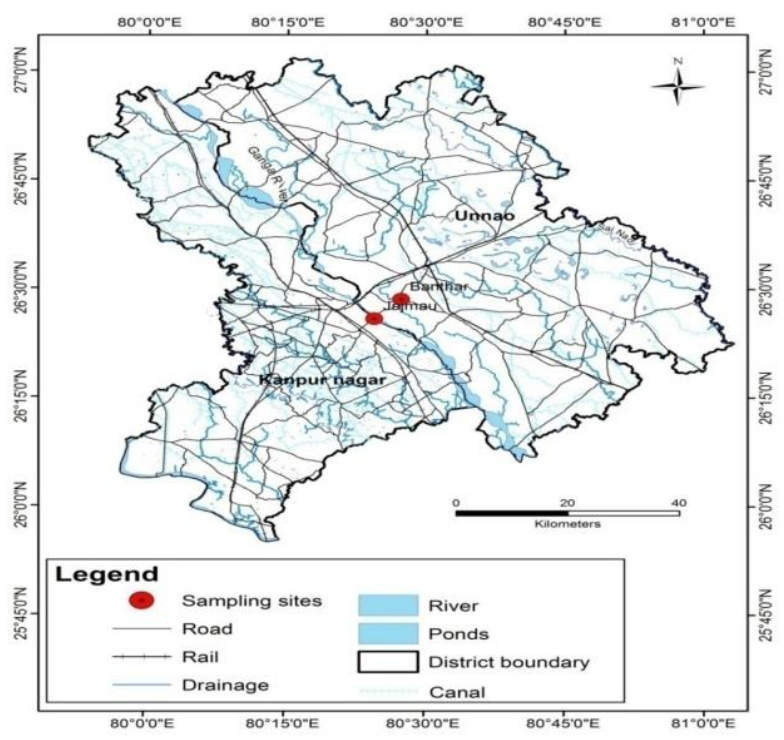

\section{Dissolved oxygen}

DO is the amount of oxygen present in water. The maximum amount of DO in the present study was $6.96 \mathrm{mgL}^{-1}$ in control and minimum DO was observed 5.09 and 5.76 $\mathrm{mgL}^{-1}$ in both sites- 1 and 2 respectively. The presence of high amount of organic contents in tannery waste water causes an increase in microbial activity which consumes dissolved oxygen in their biological activity of decomposing organic matter. Noorjahan (2004) and Sugasini and Rajgopal (2015) have also reported similar results.

\section{Biological Oxygen Demand}

In the present study, the maximum BOD was observed 58.64 and $11.75 \mathrm{mgL}^{-1}$ in $20 \%$ TWW at both sites-1 and 2 reflecting presence of organic substances (skins and hides) used as raw materials in tannery industry. High level of dissolved organic matter consumes large amount of oxygen and increase BOD level, which undergoes anaerobic processes leading to the formation of ammonia and organic acids (acetic acids and butyric acid). The main problem of BOD is the depletion of the dissolved oxygen content of stream waters caused by microbial decomposition encouraging anaerobic activity, which leads to release of noxious gases (Song et al., 2000). Similar results were reported by Mwinyihija et al., (2006).

\section{Chemical Oxygen Demand}

The COD values observed was 424.33 and $335.66 \mathrm{mgL}^{-1}$ in $20 \% \mathrm{TWW}$ at both sites 1 and 2 respectively, COD test is commonly used to measure the amount of organic compounds in water which is not degraded by microbial activity. Islam et al., (2014) have also reported increased amount of COD due to the high amount of organic compounds which are not affected by the bacterial decomposition.

\section{$\mathrm{Cr}$}

$\mathrm{Cr}$ is one of the most important pollutants released from the tanning industries in the effluent. According to Saritha and Meikandaan (2013) chrome tanning processes originates toxic metals and regular treatment systems are not eligible for the elimination of 
it. Maximum $\mathrm{Cr}$ concentration was observed 13.87 and $8.82 \mathrm{mgL}^{-1}$ in $20 \% \mathrm{TWW}$ at both sites respectively. The wastewater generated by tanneries is the major source of Chromium pollution. The chromium $(\mathrm{Cr})$ is well-known to be toxic to living organisms due to their bioaccumulation and non-biodegradable properties. The similar result of $\mathrm{Cr}$ was reported by Farhad ali et al., (2015)

It was concluded that the tannery waste water in different concentration $(5 \%, 10 \%, 15 \%$ and $20 \%$ concentration of tannery wastewater) showed a significant effect on the physicchemical parameters of fresh water $(\mathrm{pH}, \mathrm{EC}$, TDS, hardness, alkalinity, BOD, COD, chloride and $\mathrm{Cr}$ ). The parameters were also found to be higher than the prescribed discharge limits of BIS standard. The disposal of such type of tannery waste water is not safe to discharge into water bodies without proper treatment because they alter the physicochemical properties of the water creating harmful effect to aquatic ecosystem and the people residing in tanning industrial area are at high risk facing deleterious health effects even on dilution.

\section{References}

Ahmed, M.K., Das, M., Islam, M.M., Akter, M.S., Islam, S. and Abdullah M.A. 2011. Physico-Chemical Properties of Tannery and Textile Effluents and Surface Water of River Buriganga and Karnatoli, Bangladesh. J. World Appl. Sci., 12(2): 152-159.

APHA, AWWA, WEF. 1998. Standard methods for examination of water and waste water. American publication Health Association, Washington, D.C.

Azom, M.R., Mahmud, K., Yahya, S.M., Sontu, A., and Himon, S.B. 2012. Environmental Impact Assessment of Tanneries: A Case Study of Hazaribag in Bangladesh, Int. J. Environ. Sci. Develop., 3(2): 152-156.

Bhatnagar, M.K., Singh, R., Gupta, S. and
Bhatnagar, P. 2013. Study of tannery effluents and its effects on sediments of river ganga in special reference to heavy metals at Jajmau, Kanpur, India. $J$. Environ. Res. and Develop., 8(1): 56-59.

Cheng, L. and Dixon, K. 1998. Analysis of repair and mutagenesis of chromium induced DNA damage in yeast mammalian cells and transgenic mice. Environ. Hlth. Perspect., 106: 1027-1032.

Das, M., Ahmed, M.K., Islam, M.M., Akter, M.S., Islam, M.S. and Mansur, M.A. 2010. Heavy Metal Concentrations in Industrial Effluents (Tannery and Textile) and Water of Adjacent River. Terrestrial and Aquatic Environ. Toxicol., 5(1): 8-13.

Farenzena, M., Ferreira, L., Trierweiler, J.O. and Aquim, P.M. 2005. Tanneries: from waste to sustainability. Braz. Archive Biol. Technol., 48: 281-289.

Farhad, M.A., Naher, U.H.B., Chowdhury, M.S.U., Rahman, M., Hasan, M.M. 2015. Investigation on Physicochemical Parameters of Tannery Effluent, Universal J. Environ. Res. Tec., 5(3): 122-130.

Islam, B.I., Musa, A.E., Ibrahim, E.H., Salma, A.A.S. and Babiker M.E. 2014. Evaluation and characterization of tannery waste water. J. Forest Prod. Ind., 3: $141-150$.

Kambole, M.S. 2003. Managing the Water Quality of the Kafue River. In: Physics and Chemistry of the Earth, Parts $\mathrm{A} / \mathrm{B} / \mathrm{C}$. 28(20-27): 1105-1109.

Lokhande, S.R., Pravin, U, Singare, D. and Pimple, S. 2011. Study on Physicochemical parameters of waste water Effluents from Taloja Indutrial Area of Mumbai, India; Int. J Eco-system, 1(1): 1-9.

Mishra, A.K. and Mohanty, B. 2008. Acute toxicity impacts of hexavalent chromium on behavior and histopathology of gill, kidney and liver of the freshwater fish, Channa punctatus (Bloch). Environ. Toxicol Pharmacol., 26: 136- 141.

Mohan, D., Kunwar, P.S. and Vinod, K.S. 2006. Trivalent chromium removal from waste 
water using low cost activated carbon derived from agricultural waste material and activated carbon fabric cloth. $J$. Hazard. Mater., 135: 280-295.

Mohanta, M.K., Salam, M.A., Saha, A.K. and Hasan, A. 2010. Roy A.K. Effect of tannery effluents on survival and histopathological changes in different organs of Channa puntatus. Asian J. Exp. Biol. Sci., 1: 294-302.

Murali, S., Henncia, S. and Malliga, P. 2013. Bioremediation of tannery effluent using fresh water cyanobacterium oscillatoriaannae with coir path. Int. J. Environ. Sci., 3(6): 1881-1890.

Mwinyihija, M., Strachan, N.J.C., Dawson, J., Meharg, A. and Killham, K. 2006. An ecotoxicological approach to assessing the impact of tanning industry effluent on river health. Arch. Environ. Contam. Toxicol., 50: 316-324.

Navaraj, P.S. and Yasmin, J. 2012. Toxicological evaluation of tannery industry waste water on Oreochromis mossambicus. African J. Environ. Sci. Tec., 6(9): 331-336.

Noorjahan, C.M. 2004. Physicochemical characteristics, identification of fungi and biodegradation of industrial effluent. $J$. Environ. Earth Sci., 4: 32-39.

Ogbonna, J.O., Lawal, F.A., Owoeye, L.D. and Udeh, M.U. 2008. Chemical Characteristics and Fertilizing value of Primary Sludge from Tannery Effluent Treatment Plant", 6th Ann. Natl. Conf. Nigerian Inst. Sci. Technol. Univ. Ibadan, 24-27th.

Piper, C.S. 1942. Soil and plant analysis,
Monograph. Waite agricultural Research Institute, the University, Adelaide, Australia.

Saritha, B. and Meikandaan, T.P. 2013. Treatability study of tannery effluent by enhanced primary treatment, Int. J. Mod. Engin. Res., 3(1): 119-122.

Scannell, W.P.K. and Duffy, I.K. 2007. Effects of total dissolved solids on aquatic organisms: A review of literature and recommendation for salmonid species. Am. J. Environ. Sci., 3(1): 1-6.

Song, Z., Williams, C.J. and Edyvean, R.J. 2000. Sedimentation of tannery wastewater. Water Res., 34: 2171-2176.

Sugasini, A. and Rajagopal, K. 2015. Characterization of Physicochemical Parameters and heavy metal Analysis of Tannery Effluent. Int. J. Curr. Microbiol. App. Sci., 4(9): 349-359.

Vijayanand, S. and Hemapriya, J. 2014. Biosorption and detoxification of $\mathrm{Cr}(\mathrm{VI})$ by tannery effluent acclimatized halotolerant bacterial strain pv26. Int. J. Curr. Microbiol. Appl. Sci., 3: 971982.

Wang, J.R, Broderick, A.J and Barchowsky, A. 1999. Chromium Cr (VI) inhibits the transcriptional activity of nuclear factor-B by decreasing the interaction of $\mathrm{p} 65$ with cAMP-responsive element binding protein. J. Biol. Chem., 274(51): 3620736212 .

Wosnie, A. and Wondie, A. 2014. Bahir Dar tannery effluent characterization and its impact on the head of Blue Nile River, African J. Environ. Sci. Technol., 8(6): 312-318.

\section{How to cite this article:}

Shahida Parveen, Ram Bharose and Dharam Singh. 2017. Assessment of Physico-Chemical Properties of Tannery Waste Water and Its Impact on Fresh Water Quality. Int.J.Curr.Microbiol.App.Sci. 6(4): 1879-1887. doi: https://doi.org/10.20546/ijcmas.2017.604.224 